\title{
"Ilha de mata" na divisa do Brasil com Argentina e Paraguai: Parque Nacional do Iguaçú
}

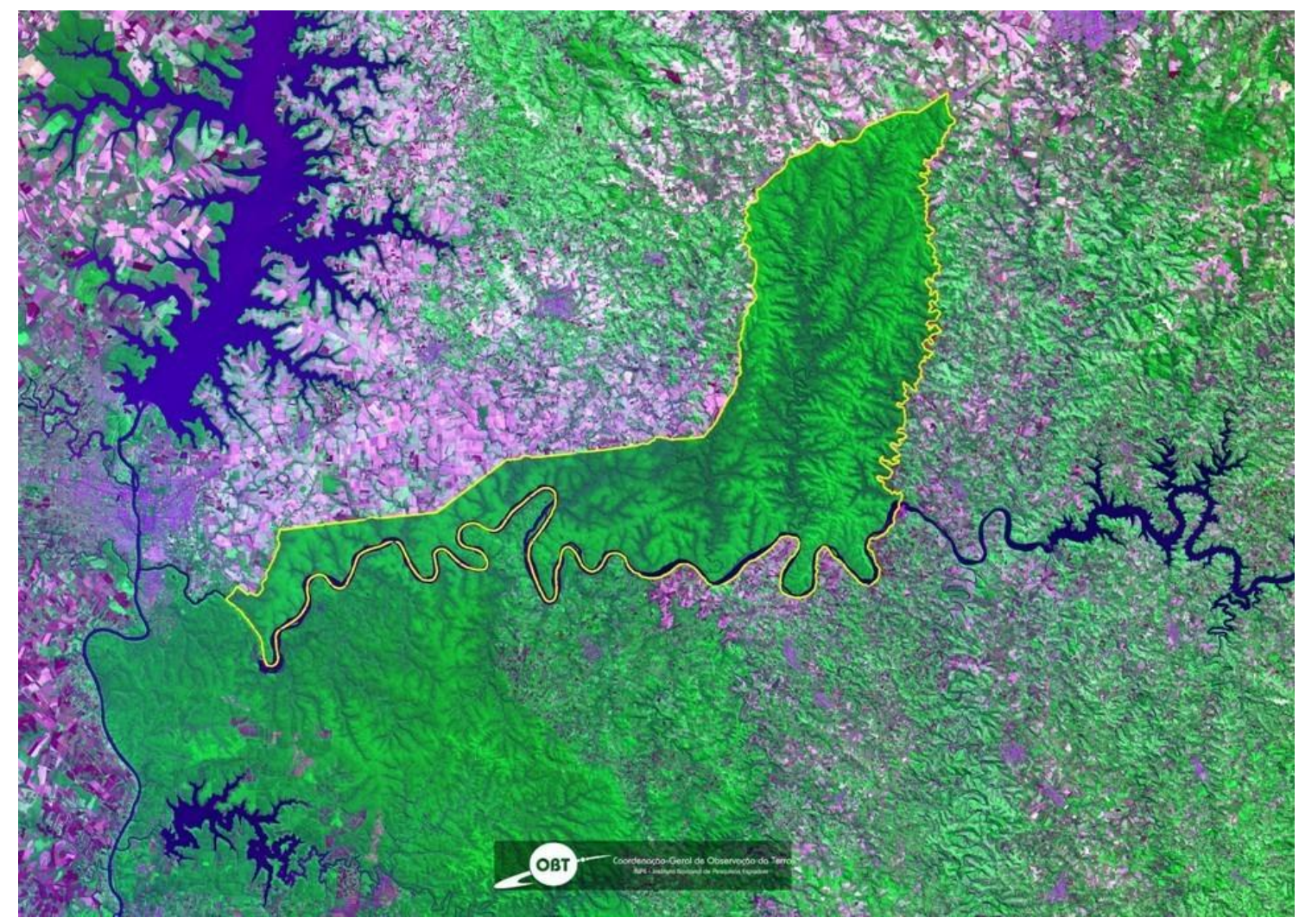

Imagem do satélite sino-brasileiro CBERS-4 na composição colorida ( $\left.\mathrm{R}_{7} \mathrm{G}_{8} \mathrm{~B}_{5}\right)$ ressaltando a vegetação (em verde) e área urbana/agricultura (em rosa) na região do Parque Nacional do Iguaçú (limites em amarelo). O Parque encontra-se na fronteira com Argentina (ao sul do Parque) e Paraguai (à oeste). Também à oeste se verifica o curso natural do Rio Paraná e seu barramento (UHE Itaipu). No interior do Parque estão destacadas as feições topográficas. Conheça mais imagens do satélite CBERS-4 na Galeria de Imagens da Coordenação de Observação da Terra/INPE. 